\title{
ПРАВОСУДДЯ ТА ВЕРХОВЕНСТВО ПРАВА: СУЧАСНI ЗАГРОЗИ
}

\author{
ЖАРОВСЬКА Ірина Мирославівна - доктор юридичних наук, професор \\ кафедри теорії, історії філософії права, Національного університету «Львівська \\ політехніка»
}

ORCID ID : https://orcid.org/0000-0003-3821-8120

DOI:10.32782/EP.2020.2.2

У статті проводиться аналіз позитивного правового досвіду реалізащй правосуддя в державах - иленах Ради Европи та Украӥні в умовах пандемї COVID-19.

Виклики съогодення, спричинені пандемією, характеризу.ться найбільшим поширенням інфекційного захворювання на території багатьох країн світу, тому вводяться обмежувальні заходи, котрі не дають повною мірою реалізувати систему правосуддя. У проаналізовані у статті нащіональні системи (Австрія, Болгарія, Боснія і Герцоговина, Вiрменія, Польща) були введені спеціальні норми з метою задоволення потреби в соціальній дистаниійності, одночасно надаючи мінімальний рівень правосуддя. Це стосується, зокрема, проваджень, пов'язаних із дітьми, опікою, домашнім насильством та триманням під вартою. Засобом можливості оптимального вирішення проблеми верховенства права та належного правосуддя під час пандемї є система електронного суду. Після відновлення, частково або повністю нормального судового процесу, судовій системі доведеться вжити заходів для забезпечення вирішення накопичених відставань, дотримуючись усіх процедурних гарантій.

Ключові слова: правосуддя, верховенство права, пандемія, загроза, суд.

\section{Постановка проблеми}

Пандемія COVID-19 зумовила зміну всієі політико-правової реальності, змінила умови суспільно-побутового життя людства. Наслідки такої трансформації повною мірою нині ще не можуть повною мірою бути оцінені. Вказане зумовлено трьома факторами: незважаючи на пом'якшення заходів безпеки, що вживалися державами на піку епідемії, все ж загроза інфікування не зникла, а лишень тимчасово призупинилася; ВООЗ застерігає про небезпеку другої хвилі загострення епідеміологічної ситуації; постпандемічне суспільство більше ніколи не стане таким, як було до загрози.

Виклики відсуваються не тільки в індивідуальному обмеженні прав особи, а також впливають на економічний та державноправовий сектор. Не оминули вони і таку сферу, як правосуддя.

Протидія полягає у наступному - реальній можливості гарантування здійснення правосуддя та потребі убезпечення членів суспільства.

Питаннями функціонування правосуддя, верховенства права та належності побудови судової гілки влади займалося багато науковців, зокрема О.Б. Верба-Сидор, Д.О. Вовк, Н.М. Грень, І. А. Кравченко, Ю.О. Косткіна, О.М. Крукевич, С.Ю. Аевицька, М. В. Оніщук, А. С. Славко та багато інших. Проте питання функціонування системи правосуддя під час пандемії COVID-19 ще не ставала предметом розгляду.

Метою иієї статті є аналіз позитивного правового досвіду реалізації правосуддя в державах - членах Ради Свропи та Україні в умовах пандемії COVID-19. 


\section{Теорія, історія держави і права, конституційне право}

\section{Виклад основних положень}

Слід погодитися з науковцями, які поняття правосуддя зводять до широкого тлумачення. Зокрема, I. Кравченко вказує, що «це правозастосовна діяльність суду 3 розгляду та вирішення у передбаченому законом процесуального порядку цивільних, господарських, кримінальних та адміністративних справ, а також конституційного судочинства, метою якого є досягнення справедливості, розв'язання конфлікту, захист прав та свобод людини, юридичних осіб, держави., та діяльність правоохоронних органів, які сприяють здійсненню судом правосуддя і забезпечують виконання його рішень, а саме: органів дізнання, досудового слідства, прокуратури та органів, які відають виконанням судових рішень, вироків і призначених покарань» [1].

В основі правосуддя $\mathrm{e}$ діяльність суду 3 метою захисту прав та свобод громадян. Безперервність цього процесу та вчасність є запорукою демократичності держави. Виклики сьогодення, спричинені пандемією COVID-19, характеризуються найбільшим поширенням інфекційного захворювання на території багатьох країн світу, тому вводяться обмежувальні заходи, котрі не дають повною мірою реалізувати систему правосуддя.

У більшості національних системах були введені спеціальні домовленості 3 метою задоволення потреби в соціальній дистанційності, одночасно надаючи мінімальний рівень обслуговування у випадках, коли відкладення матиме особливо шкідливі наслідки. Це стосується, зокрема, стосовно проваджень, пов'язаних із дітьми, опікою, домашнім насильством та триманням під вартою.

Загалом міжнародний експертний та науковий аналіз дає можливість стверджувати, що держави правильно поставили пріоритет у всіх питаннях, пов'язаних зі своїми системами охорони здоров'я та їх економікою. Це повинно супроводжуватись визнанням важливості забезпечення доступу до правосуддя - спорів, які все ще вирішуються справедливо та в розумний термін, прав - усе ще зберігається, а зловживань - усе ще виявляється та санкціонується. Обмеження, необхідні в цей над- звичайний період, повинні бути скасовані як пріоритетні.

Після відновлення, частково або повністю нормального судового процесу судовій системі доведеться вжити заходів для забезпечення вирішення накопичених відставань, дотримуючись усіх процедурних гарантій. Видається, що державам доведеться виділити додаткові ресурси для створення необхідного додаткового потенціалу.

Начальник управління юстиції та правового співробітництва Генерального директорату з прав людини та верховенства права при Раді Европи Г. Джунчер також зауважує, що «держави, в яких проводилися судові реформи до пандемії, зіткнуться з ще більшими проблемами у забезпеченні того, щоб вони змогли впоратися зі своїми звичайними навантаженнями, а також тими, що виникають внаслідок зниження продуктивності в періоди закриття або ув'язнення. У системах з великою кількістю вакантних посад для суддів та прокурорів існує ризик, що доступ до правосуддя буде негативно впливати» [2].

Европейська комісія Ради Европи з питань ефективності правосуддя створила цілий ряд інструментів та вказівок щодо оптимізації роботи судів, вирішення проблем із відставанням у судах, роботи з часовими рамками для різних видів справ, управління переходом до кібер несправедливості та залученням у поглядах користувачів правосуддя та судів. Цей інструментарій розроблений для того, щоб забезпечити, щоб заходи, вжиті державами-членами під час поточної кризи, залишалися пропорційними загрозі, спричиненою поширенням вірусу, та були обмеженими у часі.

Рада Европи застерігає 3 обережністю ставитися до обмежувальних заходів, у тому числі права на правосуддя, вказуючи, що «деякі обмежувальні заходи, прийняті державами-членами, можуть бути виправдані на основі звичайних положень Европейської конвенції про права людини (Конвенція) щодо охорони здоров'я, заходи особливого характеру можуть вимагати відхилення від норм зобов'язання держав за Конвенцією. Кожна держава повинна оцінювати, чи приймає вона заходи, які вимагають такого 
відхилення залежно від характеру та ступеня обмежень, що застосовуються до прав та свободи, захищених Конвенцією. Можливість держав зробити це важливою особливістю системи, що дозволяє продовжувати застосовувати Конвенцію та їі механізми нагляду навіть у найкритичніші часи» [3]

Інформаційний документ: Повага до демократії, верховенства права та прав людини в рамках санітарної кризи COVID-19 містить вимоги до поваги до верховенства права та демократичних принципів у надзвичайні періоди, зокрема дотримання принципу законності, обмежена тривалість режиму надзвичайного стану та заходів, обмежений обсяг законодавства про надзвичайні ситуації; принцип розподілу повноважень та перевірки виконавчої дії під час режиму надзвичайного стану та принцип необхідності. Останній і вимагає, щоб надзвичайні заходи повинні були спроможними досягти їх мети 3 мінімальною зміною нормальних правил та процедур прийняття демократичних рішень . Тому повноваження уряду видавати надзвичайні укази не повинні спричиняти карт-бланш, наданий законодавцем органам державної служби.

Проаналізуємо національні заходи, здійснені з метою протидії пандемії COVID-19 у сфері правосуддя.

Безпеку персоналу на учасників процесу Австрійська влада висуває на перший план. Тому 23 березня 2020 року були прийняті заходи подолання загрози COVID 19, де вказано, що у кримінальних справах слухання за винятком затримання та інших процедур, які не можуть бути відкладені, можуть бути відмінені, а у цивільних справах усні слухання слід проводити лише в тій мірі, в якій це абсолютно необхідно для забезпечення належного здійснення правосуддя. Офіційні акти, необхідні для надання процесуальних та сторонніх прав, можуть бути складені лише за попереднім повідомленням по телефону i, якщо це можливо, повинні бути зроблені по телефону або електронною поштою [4].

Більш ширше пояснення надає Вища судова та прокурорська рада Боснії та Герцеговини 22 березня 2020 у Рішенні з пи- тань організації робочих процесів у судах та прокуратурах Боснії та Герцеговини. Там вказано, що основні слухання у кримінальних справах мають бути перенесені, крім випадків: у якому слід розглядати питання про затримання; коли існує ризик спливу строку давності та в інших невідкладних випадках, передбачених кримінальними кодексами в Боснії та Герцеговині [5]. Такий відсилочний варіант норми не сприяє реалізації права на справедливий суд та дії принципу верховенства права. Тому вважаємо, що найкращий нормотворчий підхід обрано Вищою радою судових органів Болгарії, яка прийняла низку заходів, пов'язаних із COVID-19, де чітко визначено в додатку категорії справ, які повинні розглядатися навіть під час оголошеного в країні надзвичайного стану [6].

У свою чергу, правова норма Данії передбачає суттєвий судовий угляд, тобто передбачено можливість суддів самостійно визначати рівень невідкладності справ, але тільки 3 наступних категорій: попередні іспити перед магістратом; подовження строків та розпоряджень термінових процедур; справи опіки, коли справа відповідачів за принципом пропорційності вже не може бути відкладена; офіційні дії судового виконавця, які не можна відкласти; інші кримінальні справи, коли заради обвинуваченого, свідків чи потерпілих сторін відкладення було б непропорційним; певні випадки адміністративного опіки; реєстрація майна або земельних справ; особливо невідкладні справи про банкрутство; і певні нагальні нотаріальні справи [7]. У Польщі голова суду уповноважений визначати рівень невідкладності справ [8].

Система електронного урядування передбачає впровадження проекту «електронний суд», який ще називають електронним доступом до правосуддя, який функціонує не тільки в особливих суспільних обставинах. Його мета - це забезпечення швидкого i зручного доступу громадян до інформації про рух судової справи, час і місце іï розгляду, обміну процесуальними документами між судом та учасниками судового процесу iз застосуванням електронного цифрового підпису. 


\section{Теорія, історія держави і права, конституційне право}

Проте, реалізація права на справедливий суд під час пандемії отримала також нові можливості. Наприклад, у Республіці Вірменія уряд оголосив надзвичайний стан, суди продовжують функціонувати під час надзвичайного стану, який передбачений законом. Більшість слухань відбувалося в заочній формі. Проте певна категорія позовів, наприклад справи по догляду за дитиною, такої форми не передбачають, тому вперше в історії вірменської судової практики слухання проходили на великій відстані за допомогою технічних засобів. Щоправда, правова норма, що надавала право на це була передбачена Цивільним процесуальним кодексом [9].

В Україні ця система діє також як пілотний проєкт. Положення про автоматизовану систему документообігу суду (АСДС), затверджене рішенням Ради суддів України (РСУ) від 26.11.2010 р. №30 (у редакції рішення РСУ від 12.04.2018 р. №16), надало можливість до початку функціонування Єдиної судової інформаційно-телекомунікаційної системи (ECITC) використовувати в українських судах у тестовому режимі окремі інструменти електронного правосуддя, серед яких підсистема «Електронний суд». Сподіваємося, критична ситуація стане поштовхом для подолання проблем такої системи. Нова редакція Концепції побудови ECITC, затвердженої наказом Державної судової адміністрації України від 07.11.2019 р. №1096, визначила проблеми, які існують у судах у частині їх електронної роботи, зокрема: наявні системи автоматизації судів, органів та установ системи правосуддя не відповідають вимогам технічного захисту інформації для інформаційно-телекомунікаційних систем; сукупність розрізнених локальних баз даних судів, органів та установ системи правосуддя; не надає можливості спільної роботи 3 документами тощо [10].

\section{Висновок}

Виклики сьогодення спричинені пандемією COVID-19, характеризуються найбільшим поширенням інфекційного захворювання на території багатьох країн світу, тому вводяться обмежувальні заходи, котрі не дають повною мірою реалізувати систему правосуддя. У проаналізованих у статті національних системах (Австрія, Болгарія, Боснія і Герцоговина, Вірменія, Польща) були введені спеціальні норми з метою задоволення потреби в соціальній дистанційності, одночасно надаючи мінімальний рівень правосуддя. Це стосується, зокрема, стосовно проваджень, пов'язаних із дітьми, опікою, домашнім насильством та триманням під вартою. Засобом можливості оптимального вирішення проблеми верховенства права та належного правосуддя під час пандемії є система електронного суду. Після відновлення, частково або повністю, нормального судового процесу судовій системі доведеться вжити заходів для забезпечення вирішення накопичених відставань, дотримуючись усіх процедурних гарантій.

\section{Література}

1. Кравченко I. А., Колодочка О.Е. Поняття правосуддя та особливості його здійснення в Україні Журнал східноєвропейсъкого права. 2019. № 63. - С. 52-58.

2. Juncher H. Justice during, and after, a Time of Pandemic URL: https://www.unodc. org/dohadeclaration/en/news/2020/05/justiceduringand-aftera-time-of-pandemic.html (дата звернення: 1.06.2020)

3. Respecting democracy, rule of law and human rights in the framework of the COVID-19 sanitary crisis A toolkit for member states. Information Documents SG/Inf(2020)11 URL: $\quad$ https://rm.coe.int/sg-inf-2020-11respecting-democracy-rule-of-law-and-humanrights-in-th/16809e1f40 (дата звернення: 1.06.2020)

4. Introductory decree to deal with the current corona pandemic (SARS-CoV-2) URL: https://rm.coe.int/order-covid19-enaustria/16809d72fa

5. High Judicial and Prosecutorial Council Bosnia and Herzegovina held a telephone session on 22 March 2020 and adopted the following: Decision on the organisation of work processes in courts and prosecutor's offices in Bosnia and Herzegovina URL: https://www.coe.int/en/web/cepej/compilationcomments \#Bosnia\%20and\%20Herzegovina (дата звернення: 1.06.2020) 
6. Management of the judiciary compilation of comments and comments by country URL: https://www.coe.int/en/web/ cepej/compilation-comments\#Bulgaria (дата звернення: 1.06.2020)

7. Plan for reopening the Courts of Denmark. 14 May 2020 URL: https://rm.coe. int/plan-for-reopening-of-the-courts-ofdenmark/16809e5a14 (дата звернення: $1.06 .2020)$

8. Act of 31 March 2020 amending the Act on special solutions related to the prevention and combating of COVID-19 URL: https://www.coe.int/en/web/cepej/compilationcomments\#Poland (дата звернення: 1.06.2020)

9. Armenia Management of the judiciary - compilation of comments and comments by country URL: https://www.coe.int/en/web/ cepej/compilation-comments\#Armenia (дата звернення: 1.06.2020)

10. Венгриняк X. Все, що потрібно знати про електронний суд Юридична газета. 2019. №51-52. (705-706).

\section{Iryna Myroslavivna Zharovska JUSTICE AND THE RULE OF LAW: CURRENT THREATS}

The article analyzes the positive legal experience in the administration of justice in the member states of the Council of Europe and Ukraine in the context of the COVID-19 pandemic.

Today's challenges caused by the pandemic are characterized by the highest prevalence of infectious diseases in many countries around the world, so restrictive measures are introduced that do not allow the full implementation of the justice system. In the national systems analyzed in the article (Austria, Bulgaria, Bosnia and Herzegovina, Armenia, Poland), special rules were introduced to meet the need for social distance, while providing a minimum level of justice. This applies in particular to proceedings involving children, guardianship, domestic violence and detention. An e-court system is a means of optimally addressing the rule of law and due process during a pandemic. Once a normal, partially or completely normal trial has resumed, the judiciary will have to take steps to ensure that the accumulated backlogs are resolved, in compliance with all procedural guarantees.

Key words: justice, rule of law, pandemic, threat, court. 